\title{
High Temperature Mechanical Properties of Partially Sinter-Forged Porous Anisotropic Silicon Nitride
}

\author{
Naoki KONDO, Yoshiaki INAGAKI, ${ }^{*}$ Jian-Feng YANG and Tatsuki OHJI \\ Synergy Materials Research Center, National Institute of Advanced Industrial Science and Technology (AIST), \\ 2268-1, Shimo-Shidami, Moriyama-ku, Nagoya-shi 463-8687 \\ *Synergy Ceramics Laboratory, Fine Ceramics Research Association (FCRA), 2268-1, Shimo-Shidami, Moriyama-ku, Nagoya-shi $463-8687$
}

\author{
部分鍛造焼結により作製した異方性窒化ケイ素の高温機械特性 \\ 近藤直樹·稲垣良昭* $\cdot$ 楊 建峰·大司達樹 \\ 産業技術総合研究所シナジーマテリアル研究センター, 463-8687 名古屋市守山区下志段味 2268-1 \\ *ファインセラミックス技術研究組合シナジーセラミックス研究所, 463-8687 名古屋市守山区下志段味 2268-1
}

\begin{abstract}
Mechanical properties of porous anisotropic silicon nitrides, fabricated by a partial sinter-forging technique, were investigated in the temperature range from room temperature (R.T.) to $1400^{\circ} \mathrm{C}$. The fabricated specimens, with porosity of about $24 \%$, exhibited a relatively high strength as well as a high fracture energy. These good properties were maintained even at temperatures as high as $1300^{\circ} \mathrm{C}$. This achievement of good properties is very likely due to the combined effects of grain alignment, presence of pores between grains and yttria sintering aid refractoriness. [Received September 19, 2002; Accepted February 7, 2003]
\end{abstract}

Key-words : Silicon nitride, Porous material, Anisotropic material, Strength, Fracture energy, High temperature

\section{Introduction}

Recently, high strength porous silicon nitrides have been developed by controlling their porous microstructures. ${ }^{1)-6)}$ One of the most important developments in porous silicon nitride $\left(\mathrm{Si}_{3} \mathrm{~N}_{4}\right)$ is the development of anisotropic microstructures, where rod-like silicon nitride grains display a high degree of directionality. ${ }^{1), 4), 6)}$ This microstructure formation results in excellent mechanical properties when a tensile stress is applied in the alignment direction.

The authors have successfully fabricated such porous anisotropic silicon nitrides using a partial sinter-forging technique. $\left.{ }^{6)}, 7\right)$ In this procedure, rod-like silicon nitride grains are formed during soaking at elevated temperatures, and the grains are aligned during sinter-forging by the applied stress. The fabricated specimens showed relatively high bending strength as well as high fracture energy. By choosing suitable fabrication conditions, a relatively high strength of $780 \mathrm{MPa}$, or a high fracture energy of 266 $\mathrm{J} \cdot \mathrm{m}^{-2}$, was achieved in the fabricated specimen with porosity of about $24 \%$ at room temperature (R.T.).

The fabricated specimens contained 5 mass $\%$ yttria $\left(\mathrm{Y}_{2} \mathrm{O}_{3}\right)$ as a sintering aid. It has been established that yttria is one of the most promising aids to achieve high temperature strength. $\left.{ }^{8}\right)$ Thus, the fabricated specimens are expected to show good high temperature mechanical properties. This study aims to investigate high temperature mechanical properties of the porous anisotropic silicon nitrides fabricated by the partial sinter-forging technique.

\section{Experimental}

The two specimens developed in the previous work ${ }^{7)}$ having the same composition and porosity, but different grain size, were provided for the present study. Here, the fabrication procedure is briefly described. $\alpha$-silicon nitride powder (E10, Ube Industries Ltd., Tokyo, Japan), mixed with 5 mass $\% \mathrm{Y}_{2} \mathrm{O}_{3}$ (UF, Shin-Etsu Chemical Co., Ltd., Tokyo, Japan) as a sintering aid, was ball-milled for $50 \mathrm{~h}$ in methanol using silicon nitride balls. The powder was dried, sieved and compacted with a uniaxial pressure of $2.5 \mathrm{MPa}$ in a graphite die with a base of $45 \times 45 \mathrm{~mm}$. Partial sinter-forg- ing was conducted using a hot-press. An atmosphere of nitrogen gas $(99.99 \%)$ under $0.9 \mathrm{MPa}$ pressure was maintained throughout the sinter-forging process. The graphite die was heated up to $1850^{\circ} \mathrm{C}$ at a rate of $10^{\circ} \mathrm{C} \cdot \mathrm{min}^{-1}$. After soaking for $30 \mathrm{~min}$, partial sinter-forging was conducted with a uniaxial mechanical force of $58800 \mathrm{~N}$ (approximately $30 \mathrm{MPa}$ ). The total sintering time (= soaking time + partial sinter-forging time) at $1850^{\circ} \mathrm{C}$ was varied from 3 to $8 \mathrm{~h}$. Piston travel was restricted to control the density of the sintered specimens. After sintering, the die was cooled at a rate of $10^{\circ} \mathrm{C} \cdot \mathrm{min}^{-1}$ to $<1000^{\circ} \mathrm{C}$. Both specimens had a porosity of $24 \%$, and further information has been reported in Ref. 7).

Specimens of $3 \times 4 \times 45 \mathrm{~mm}$ for measuring bending strength were cut from the partially sinter-forged body so that the stress face was perpendicular to the pressing direction. Three-point bending strength was measured with a span of $30 \mathrm{~mm}$ and a displacement rate of $0.5 \mathrm{~mm} \cdot \mathrm{min}^{-1}$ at elevated temperatures as well as at R.T. Fracture energy was measured by chevron-notched beam (CNB) method. The employed CNB specimen geometry and testing procedures were the same as those of the previous study. ${ }^{9)} \mathrm{CNB}$ specimen had dimensions of $4 \times 3 \times 45 \mathrm{~mm}$ with regular triangle shaped ligament (edge length was $3 \mathrm{~mm}$ ). Initial crack length was $1.4 \mathrm{~mm}$ and width of the chevron-notch was $0.1 \mathrm{~mm}$. Measurements were performed in three-point bending with a span of $30 \mathrm{~mm}$ and a displacement rate of $0.01 \mathrm{~mm} \cdot \mathrm{min}^{-1}$. The measurements at elevated temperatures were done in nitrogen gas atmosphere. Fracture surfaces of $\mathrm{CNB}$ specimens were observed by scanning electron microscopy (SEM).

\section{Results and discussion}

The fractured surfaces of the fabricated specimens are shown in Fig. 1. They were taken from the CNB specimens tested at R.T. (to be described later). Both specimens had porosity of $24 \%$. The specimens mainly consisted of rod-like silicon nitride grains. Protruding rod-like grains as well as holes or hollows are also observed in the micrographs. The grains in the specimen with total sintering time of $8 \mathrm{~h}$ (here- 


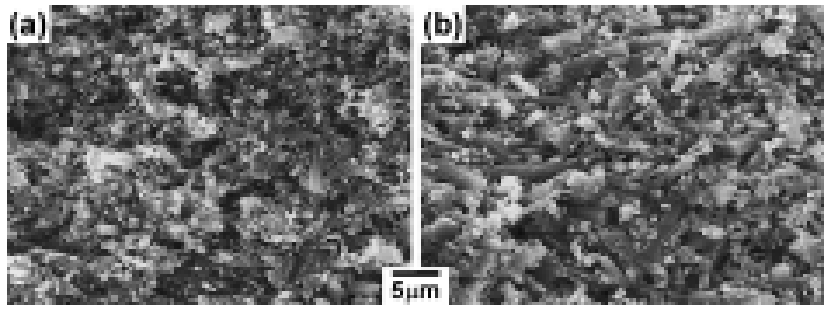

Fig. 1. Fractured surfaces of the partially sinter-forged silicon nitrides.

Total sintering time was (a) $3 \mathrm{~h}$ and (b) $8 \mathrm{~h}$, respectively.

Sinter-forging direction was vertical.

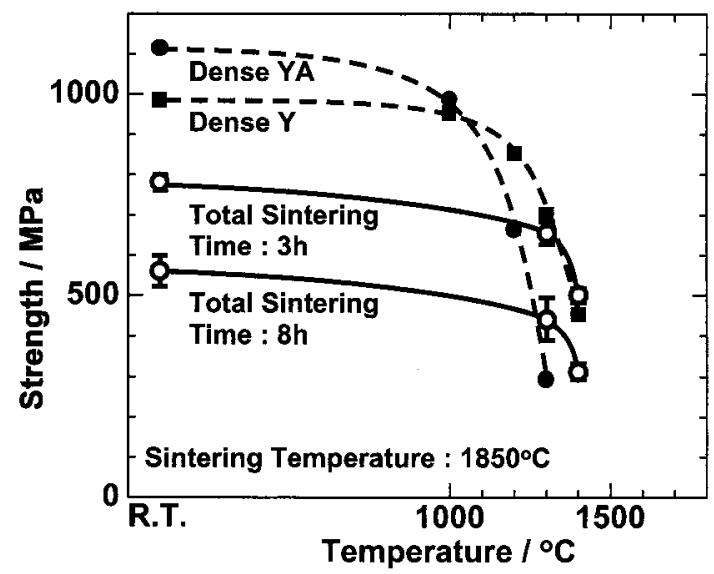

Fig. 2. Temperature dependence of strength of the partially sinter-forged silicon nitrides.

The results were compared to those of previous dense silicon nitrides.

Dense YA: Yttria and Alumina sintering aids (Ref. 10)

Dense Y: Yttria sintering aid (Ref. 11)

after $8 \mathrm{~h}$ specimen) were more coarsened compared with the specimen with total sintering time of $3 \mathrm{~h}$ (hereafter $3 \mathrm{~h}$ specimen). Grains were somewhat aligned perpendicularly to the pressing direction, as can be seen in the micrographs. This grain alignment (anisotropy) was also examined by $\mathrm{X}$-ray diffraction analysis, ${ }^{7)}$ and found that the anisotropy of the $8 \mathrm{~h}$ specimen was little higher than that of the $3 \mathrm{~h}$ specimen.

Measured strength and fracture energy are shown in Figs. 2 and 3 , respectively, together with previous dense silicon nitrides. ${ }^{10), 11)}$ Relatively high strength of $780 \mathrm{MPa}$ or high fracture energy of $266 \mathrm{~J} \cdot \mathrm{m}^{-2}$ are achieved in the partially sinter-forged specimens at R.T. Especially, fracture energy of the $8 \mathrm{~h}$ specimen was five times higher than that of the isotropic dense material. ${ }^{10)}$ As densities of the specimens were lowered by introducing pores, they exhibited relatively high specific strength (= strength/density). Specific strength of the $3 \mathrm{~h}$ specimen, $321 \mathrm{MPa} \cdot \mathrm{kg}^{-1} \cdot \mathrm{m}^{3}$, was almost comparable to that of isotropic dense ones, $300-350 \mathrm{MPa} \cdot \mathrm{kg}^{-1} \cdot \mathrm{m}^{3},{ }^{10), 11)}$ for instance.

The specimens showed good strength and fracture energy even at elevated temperatures up to $1300^{\circ} \mathrm{C}$. Strength degradation was observed to be less than $10 \%$ at $1300^{\circ} \mathrm{C}$. However, at $1400^{\circ} \mathrm{C}$, strength largely decreased. This good strength should be due to the refractoriness of yttria sintering aid. Similar degradation behavior has been observed in dense silicon nitrides with yttria aid,11) whose strength maintain up to $1200-1300^{\circ} \mathrm{C}$. An example of a silicon nitride

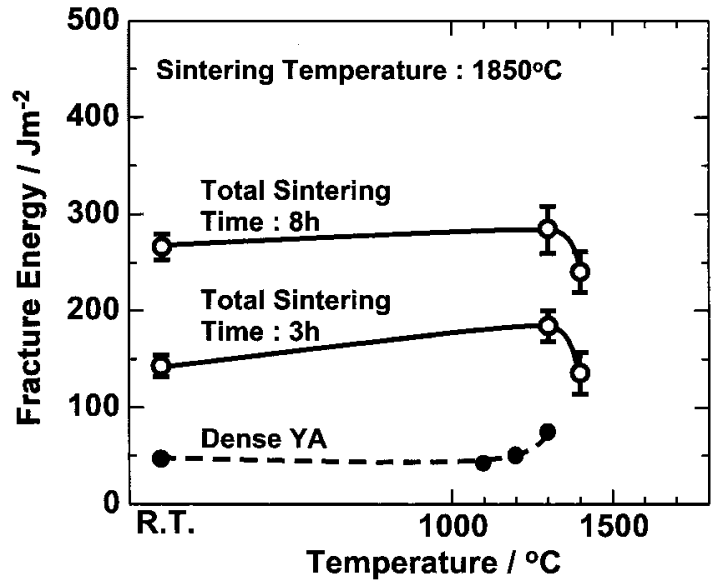

Fig. 3. Temperature dependence of fracture energy of the partially sinter-forged silicon nitrides.

The results were compared to that of previous dense silicon nitride. Dense YA: Yttria and Alumina sintering aids (Ref. 10)

with 8 mass $\%$ yttria is shown in Fig. 2. Fracture energy slightly increased at $1300^{\circ} \mathrm{C}$, then decreased at $1400^{\circ} \mathrm{C}$. Throughout the temperature range from R.T. to $1400^{\circ} \mathrm{C}$, the $3 \mathrm{~h}$ specimen, which had smaller grains, showed higher strength, but lower fracture energy, compared with the $8 \mathrm{~h}$ specimen with larger grains. Such relationship has been well known as a "trade-off relationship" in conventional dense isotropic silicon nitride. ${ }^{12)}$ Porous anisotropic silicon nitrides in this work also seemed to follow the relationship.

As mentioned, porous anisotropic silicon nitride can show high strength and high fracture energy in specific direction. This achievement of good properties even at elevated temperatures is very likely due to the combined effects of grain alignment, presence of pores between grains and yttria sintering aid refractoriness.

At room temperature, concurrent achievement of strength and fracture energy has been considered to be due to the grain alignment effects as well as the presence of pores between grains. ${ }^{7)}$ Here the mechanisms are briefly described. First, alignment of rod-like grains leads to an effective operation of grain bridging and pull-out, which are major crack wake toughening mechanisms in silicon nitride. ${ }^{13), 14)}$ The silicon nitrides with such microstructure show steep increment of fracture resistance in short crack propagation, namely steep $R$-curve behavior. This steep $R$-curve behavior also leads to the improved strength. ${ }^{15)}$ Second, the presence of pores around the aligned rod-like grains presumably enhances grain pull-out and bridging, which leads to higher fracture energy as well as higher strength. ${ }^{1), 4}$

At elevated temperature, softening of grain boundary glassy phase should be considered to discuss the strength and fracture energy. Strength of the present porous silicon nitrides decrease above $1300^{\circ} \mathrm{C}$, since softening of glassy phase occurs at the higher temperature range. This is similar to the previous dense silicon nitrides with yttria aid.11) On the other hand, fracture energy exhibited somewhat different behavior to that of dense ones. Temperature dependence of strength and fracture energy of a dense silicon nitride with yttria and alumina sintering aids are shown in Figs. 2 and 3, respectively. ${ }^{10)}$ In dense silicon nitrides, increment of strength and decrement of fracture energy occur concurrently against the temperature. This is because softened glassy phase enhances viscoelastic behavior and pull-out of rod-like grains without being broken. In porous 
silicon nitride, however, effect of softening seemed to be reduced at elevated temperatures, because pull-out of grains has already been enhanced at R.T.. Thus, fracture energy increased a little at $1300^{\circ} \mathrm{C}$. Moreover, at $1400^{\circ} \mathrm{C}$, glassy phase was so softened that bridging and pull-out could not work effectively, resulted in the decrement of fracture energy.

\section{Conclusion}

Mechanical properties of porous anisotropic silicon nitrides, fabricated by a partial sinter-forging technique, were investigated in the temperature range from room temperature (R.T.) to $1400^{\circ} \mathrm{C}$. The mechanical properties of the fabricated specimens with porosity of about $24 \%$ depended on their grain size. The specimens with smaller grains exhibited a relatively high strength of $780 \mathrm{MPa}$ at R.T., which degradation was observed to be less than $10 \%$ at $1300^{\circ} \mathrm{C}$. The specimens with larger grains showed a high fracture energy of $266 \mathrm{~J} \cdot \mathrm{m}^{-2}$ at R.T., which slightly increased at $1300^{\circ} \mathrm{C}$. Thus, the good properties were maintained even at temperatures as high as $1300^{\circ} \mathrm{C}$. This achievement of good properties even at elevated temperatures is very likely due to the combined effects of grain alignment, presence of pores between grains and yttria sintering aid refractoriness.

Acknowledgment This work has been supported by METI, Japan, as part of the Synergy Ceramics Project. Part of the work has been supported by NEDO. The authors are members of the Joint Research Consortium of Synergy Ceramics.

\section{References}

1) Shigegaki, Y., Brito, M. E., Hirao, K., Toriyama, M. and
Kanzaki, S., J. Am. Ceram. Soc., Vol. 80, pp. 495-498 (1997). 2) Kawai, C. and Yamakawa, A., J. Am. Ceram. Soc., Vol. 80, pp. 2705-2708 (1997).

3) Yang, J. F. and Ohji, T., Ceram. Trans., Vol. 115, pp. 481-488 (2000).

4) Inagaki, Y., Ohji, T., Kanzaki, S. and Shigegaki, Y., J. Am. Ceram. Soc., Vol. 83, pp. 1807-1809 (2000).

5) Yang, J. F., Zhang, G. J. and Ohji, T., J. Mater. Res., Vol. 16, pp. 1916-1918 (2001).

6) Kondo, N., Suzuki, Y. and Ohji, T., J. Mater. Res., Vol. 16, pp. 32-34 (2001).

7) Kondo, N., Inagaki, Y., Suzuki, Y. and Ohji, T., Mater. Sci. Eng. A, Vol. 335, pp. 26-31 (2002).

8) Cinibulk, M. K., Thomas, G. and Johnson, S. M., J. Am. Ceram. Soc., Vol. 75, pp. 2050-2055 (1992).

9) Ohji, T., Goto, Y. and Tsuge, A., J. Am. Ceram. Soc., Vol. 74, pp. 739-745 (1991).

10) Kondo, N., Inagaki, Y., Suzuki, Y. and Ohji, T., J. Am. Ceram. Soc., Vol. 84, pp. 1791-1796 (2001).

11) Rendtel, A., Huebner, H., Herrmann, M. and Schubert, C., J. Am. Ceram. Soc., Vol. 81, pp. 1109-1120 (1998).

12) Kanzaki, S., Brito, M. E., Valecillos, M. C., Hirao, K. and M. Toriyama, M., J. Eur. Ceram. Soc., Vol. 17, pp. 1841-1847 (1997).

13) Becher, P. F., J. Am. Ceram. Soc., Vol. 74, pp. 255-269 (1991).

14) Becher, P. F., Hwang, S. L., Lin, H. T. and Tiegs, T. N., "Tailoring of Mechanical Properties of $\mathrm{Si}_{3} \mathrm{~N}_{4}$ Ceramics," NATO ASI Series, Series E, Applied Sciences, Vol. 276, Ed. by M. J. Hoffmann and G. Petzow, Kluwer Academic Publishers, Dordrecht, The Netherlands (1994) pp. 87-100.

15) Ohji, T., Hirao, K. and Kanzaki, S., J. Am. Ceram. Soc., Vol. 78, pp. 3125-3128 (1995). 